\title{
PENGEMBANGAN VIDEO PEMBELAJARAN KALKULUS DIFERENSIAL BERBASIS PEN TABLET
}

\author{
Marfi Ario ${ }^{1}$, Annajmi $^{2}$, Ratri Isharyadi ${ }^{3}$ \\ ${ }_{1,2.3}$ Universitas Pasir Pengaraian, Jl. Tuanku Tambusai, Rokan Hulu, Riau \\ marfi.ario.92@gmail.com
}

\begin{abstract}
One of the important subjects in the mathematics education program is differential calculus. One of the problems in differential calculus lectures is the low student learning outcomes. One of the obstacles faced is the difficulty of students in understanding lecture material through textbooks. Students understand more easily if it is explained verbally. To answer this problem, this research was conducted to develop alternative teaching materials in the form of pen tablet-based learning videos. The main objective of this research is to produce valid, practical, and effective differential calculus learning videos. In accordance with the research objectives, this type of research is development research. The research subjects were students of the Pasir Pengaraian University mathematics education study program who took the differential calculus course at T.A 2020/2021. This development research stage refers to the Plomp model which consists of 3 phases: preliminary research, prototyping stage, and assessment phase. The research instrument was in the form of a questionnaire filled out by material experts and media experts to measure the validity of the video, a questionnaire filled out by students to measure the practicality of the video, and a written test to measure the effectiveness of the video. The results showed that the pen tablet-based differential calculus learning video was declared valid with very good criteria, practical and effective with good criteria.
\end{abstract}

Keywords: Learning Videos, Differential Calculus, Pen Tablet.

\begin{abstract}
Abstrak
Salah satu mata kuliah penting dalam program studi pendidikan matematika adalah kalkulus diferensial. Salah satu permasalahan pada perkuliahan kalkulus diferensial yaitu rendahnya hasil belajar mahasiswa. Salah satu kendala yang dihadapi adalah sulitnya mahasiswa dalam memahami materi perkuliahan melalui buku teks. Mahasiswa lebih mudah mengerti jika dijelaskan secara lisan. Untuk menjawab permasalahan tersebut, maka penelitian ini dilakukan untuk mengembangkan bahan ajar alternatif berupa video pembelajaran berbasis pen tablet. Tujuan utama penelitian ini adalah menghasilkan video pembelajaran kalkulus diferensial yang valid, praktis, dan efektif. Sesuai dengan tujuan penelitian tersebut maka jenis penelitian ini adalah penelitian pengembangan. Subjek penelitian adalah mahasiswa program studi pendidikan matematika Universitas Pasir Pengaraian yang mengambil mata kuliah kalkulus diferensial pada T.A 2020/2021. Tahapan penelitian pengembangan ini mengacu kepada model Plomp yang terdiri dari 3 fase, yaitu: preliminary research, prototyping stage, assessment phase. Instrumen penelitian ini berupa angket yang diisi oleh ahli materi dan ahli media untuk mengukur validitas video, angket yang diisi oleh mahasiswa untuk mengukur praktikalitas video, dan tes tertulis untuk mengukur efektifitas video. Hasil penelitian menunjukkan video pembelajaran kalkulus diferensial berbasis pen tablet dinyatakan valid dengan kriteria sangat baik, praktis dan efektif dengan kriteria baik.
\end{abstract}

Kata kunci: Video Pembelajaran, Kalkulus Diferensial, Pen Tablet

\section{PENDAHULUAN}

Salah satu mata kuliah penting yang diajarkan di program studi pendidikan matematika adalah kalkulus diferensial. Mata kuliah ini sangat penting karena menjadi dasar bagi banyak mata kuliah lainnya seperti kalkulus integral, kalkulus peubah banyak, analisis kompleks, program linear, dan sebagainya. Kegagalan pada mata kuliah ini akan menimbulkan kesulitan pada matakuliah berikutnya. 
Oleh karena itu, penguasaan yang baik pada kalkulus diferensial menjadi hal wajib yang harus dimiliki setiap mahasiswa.

Data hasil ujian mahasiswa menunjukkan penguasaan materi kalkulus diferensial masih rendah (54\%). Masih ada 46\% materi yang belum dikuasai dengan baik. Mencermati hal tersebut, maka perlu dilakukan upaya untuk dapat meningkatkan perolehan hasil belajar tersebut.

Berdasarkan hasil observasi dan wawancara terhadap mahasiswa diperoleh informasi bahwa mahasiswa kurang bahkan tidak mengerti dengan penjelasan yang ada di buku teks kalkulus. Mereka lebih senang mendengarkan penjelasan secara lisan daripada harus membaca buku. Hal ini dapat dimaklumi karena kampus tempat peneliti mengajar merupakan kampus swasta kecil yang mahasiswanya kebanyakan adalah yang tidak lulus dari kampus-kampus negeri. Sehingga sebagian besar mahasiswa memiliki kemampuan akademik dibawah rata-rata. Hal ini terkonfirmasi melalui penelitian (Ario, 2019) yang menunjukkan bahwa kemampuan awal mahasiswa di kampus ini sangat rendah dengan rata-rata penguasaan $19,55 \%$.

Selain kesulitan dalam memahami materi melalui buku teks, permasalahan lain yang dihadapi mahasiswa adalah sering lupa dengan materi yang telah dipelajari. Mereka biasanya paham ketika dijelaskan oleh dosen saat di kelas, tetapi setelah beberapa minggu mereka lupa dengan materi yang sudah dipelajari.

Mencermati hal tersebut maka perlu inovasi bahan ajar perkuliahan untuk menjawab permasalahan tersebut. Jika selama ini bahan ajar identik dengan buku, maka salah satu inovasi yang dapat dilakukan adalah dengan menyediakan bahan ajar berbentuk video. Selain memudahkan mahasiswa dalam memahami materi dibandingkan melalui buku teks, video pembelajaran juga dapat ditonton berulang kali. Sehingga ketika mahasiswa lupa dengan suatu materi, mereka dapat memutar kembali video pembelajaran (Ario, 2019). Selain itu video pembelajaran juga memberikan keuntungan lain, yaitu mahasiswa dapat mempelajari suatu materi dengan kecepatan belajar masingmasing, karena video pembelajaran dapat dijeda (pause) untuk mencatat hal-hal penting dan dilanjutkan kembali oleh mahasiswa sesuai kebutuhan masing-masing (Anggraeni dkk., 2019).

(Purwanti, 2015) menyatakan bahwa video berkenaan dengan apa yang dilihat, utamanya gambar hidup (bergerak; motion) yang dalam proses perekaman dan penayangannya membutuhkan teknologi. (Chandra \& Nugroho, 2016) menjelaskan bahwa dalam pembelajaran ada 2 macam video yang dapat digunakan. Pertama, video yang sengaja dibuat atau didesain untuk pembelajaran. Kedua, video yang tidak didesain untuk pembelajaran, namun dapat digunakan atau dimanfaatkan untuk menjelaskan sesuatu hal yang berkaitan dengan pembelajaran. Video yang pertama dibuat khusus sesuai dengan materi dan fungsinya sebagai pengganti dosen. Video ini bersifat interaktif terhadap mahasiswa. Peran pengajar yang menggunakan video ini adalah sebagai pendamping dan fasilitator. Video kedua contohnya adalah video dokumenter, animasi, dan sejenisnya. Adapun jenis video yang 
dikembangkan pada penelitian ini adalah video jenis pertama yang dalam proses pembuatannya berbasis pen tablet.

Video pembelajaran telah dikembangkan juga oleh beberapa peneliti, namun bentuk videonya adalah video pembelajaran animasi. Artinya bukan video yang menampilkan pengajaran oleh pengajar langsung layaknya mengajar di papan tulis di kelas. Selain itu ada juga video yang menampilkan guru yang sedang mengajar di kelas. Video ini merekam aktifitas seseorang yang sedang mengajar menggunakan spidol dan papan tulis. Adapun video yang dikembangkan pada penelitian ini berbeda dengan video-video yang ada tersebut. Pada penelitian ini, pengajar menuliskan materi sambil menjelaskannya seperti layaknya pengajar di kelas, hanya saja proses rekamannya bukan merekam aktifitas pengajar, tetapi merekam hasil tulisan dan suara pengajar. Bentuk video seperti ini dalam proses pembuatan dan perekamannya memerlukan beberapa software dan peralatan khusus yang disebut pen tablet.
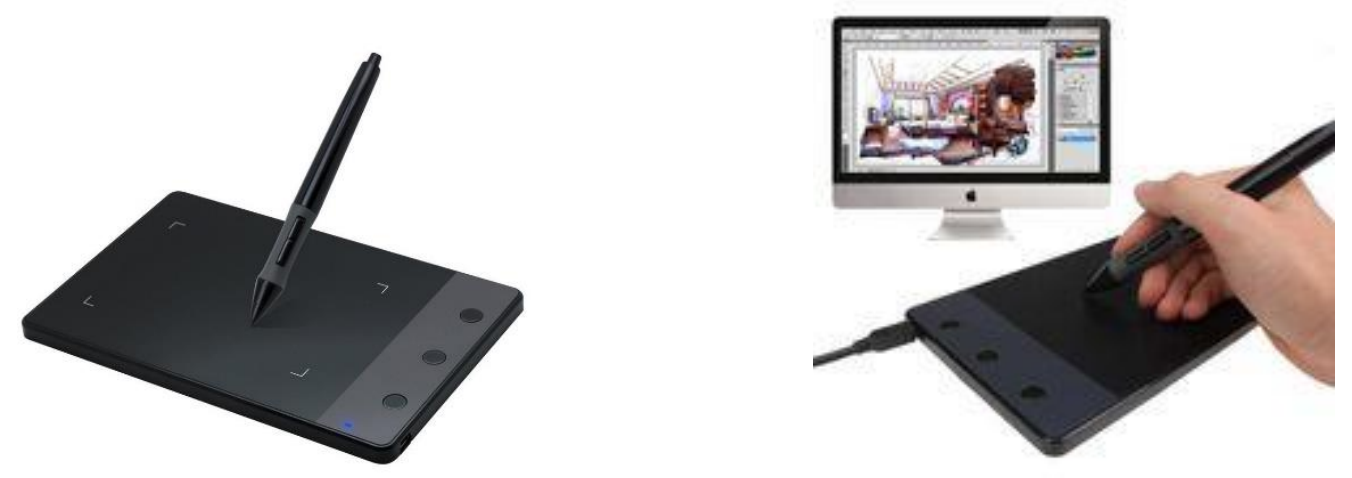

Gambar 1. Pen tablet

Pen tablet merupakan alat yang digunakan oleh graphic designer untuk membuat gambar atau animasi. Dalam dunia pendidikan, pen tablet dapat dimanfaatkan untuk menulis di layar laptop layaknya menulis di kertas. Dengan menggunakan aplikasi tambahan screen recording yang banyak tersedia diinternet, maka tulisan-tulisan yang dibuat di layar laptop tersebut dapat direkam. Hasil rekaman tersebut juga dapat dilengkapi dengan suara penjelasan tentang apa yang ditulis. Perpaduan tulisan dan suara penjelasan tersebut akan menjadi sebuah video pembelajaran. Sehingga mahasiswa bukan hanya membaca apa yang tertulis, tapi juga dapat mendengarkan penjelasan dari yang tertulis tersebut. Hal ini diharapkan dapat menjadi solusi dari masalah yang dihadapi mahasiswa, yaitu kesulitan dalam memahami buku teks yang hanya ada tulisan tanpa penjelasan suara. Hal ini sesuai dengan hasil penelitian oleh Franke, et al (Rhine, 2015) yang menunjukkan bahwa video telah terbukti menjadi alat yang berguna bagi para guru untuk membuat siswa berpikir sungguh-sungguh dan memberikan lingkungan yang lebih dinamis dibandingkan melalui tulisan langsung.

Beberapa penelitian lain yang menggunakan video pembelajaran menunjukkan hasil bahwa penggunaan video pembelajaran dapat meningkatkan hasil belajar dan keaktifan belajar siswa/ mahasiswa (Pritandhari \& Ratnawuri, 2015; Purwanti, 2015; Rebowo, 2014; Saloko dkk., 2013). 
Berdasarkan hasil penelitian tersebut, keberadaan video pembelajaran dirasa perlu dalam perkuliahan kalkulus diferensial untuk mengatasi permasalahan yang dihadapi.

Berdasarkan permasalahan yang dihadapi serta melihat kemanfaatan dari video pembelajaran dari berbagai penelitian, maka penelitian ini dilakukan dengan tujuan untuk mengembangkan video pembelajaran kalkulus diferensial yang valid, praktis, dan efektif. Dengan adanya video ini diharapkan terjadinya peningkatan penguasaan materi kalkulus diferensial khususnya bagi mahasiswa pendidikan matematika Universitas Pasir Pengaraian.

\section{METODE}

Penelitian ini digolongkan sebagai penelitian pengembangan. Metode penelitian dan pengembangan dapat diartikan sebagai cara ilmiah untuk meneliti, merancang, memproduksi, dan menguji validitas produk yang dihasilkan (Sugiyono, 2015). Penelitian ini bertujuan untuk menghasilkan video pembelajaran kalkulus diferensial berbasis pen tablet yang valid, praktis, dan efektif yang khususnya dapat digunakan mahasiswa Program Studi Pendidikan Matematika Universitas Pasir Pengaraian.

Penelitian ini dilaksanakan di Universtias Pasir Pengaraian pada tahun 2020. Subjek penelitian adalah mahasiswa pendidikan matematika semester I yang mengambil mata kuliah Kalkulus Diferensial.

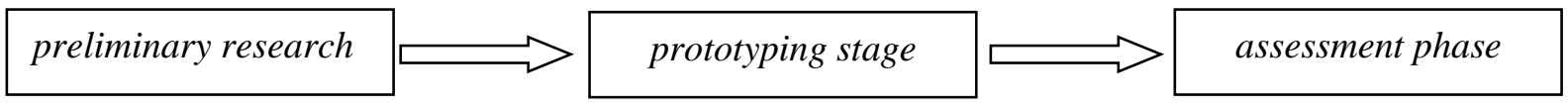

Gambar 2. Diagram alir penelitian

Model pengembangan yang digunakan pada penelitian ini merujuk kepada model pengembangan Plomp yang terdiri dari tiga langkah yaitu preliminary research, prototyping stage, dan assessment phase (Plomp \& Nieveen, 2010). Pada tahap preliminary research dilakukan review literatur, analisis kebutuhan dilapangan dan membuat rancangan awal tentang produk yang akan dikembangkan. Tahapan ini diperlukan untuk dapat membuat video pembelajaran yang sesuai dengan karakteristik mahasiswa di Program Studi Pendidikan Matematika Universitas Pasir Pengaraian, sehingga produk yang dihasilkan benar-benar dapat menyelesaikan masalah yang dihadapi di lapangan.

Pada tahap prototyping stage, dilakukan pembuatan video pembelajaran berbasis pen tablet. Selain itu pada tahapan ini juga dilakukan evaluasi terhadap video yang telah dibuat melalui penilaian para ahli. Penilaian dilakukan pada dua aspek yaitu aspek isi dan aspek tampilan. Tujuan dari tahapan ini adalah dihasilkannya video pembelajaran yang valid berdasarkan penilaian para ahli.

Pada tahap assessment phase, video pembelajaran digunakan dalam proses pembelajaran. Fase ini dilakukan untuk menilai apakah video yang telah dikembangkan dapat digunakan dengan 
mudah oleh mahasiswa dan juga untuk menilai apakah video pembelajaran dapat memberikan hasil yang efektif terhadap hasil belajar mahasiswa. Tujuan tahapan ini adalah dihasilkannya video pembelajaran yang praktis dan efektif.

Data pada penelitian ini terdiri dari data validitas, praktikalitas, dan efektivitas. Data validitas diperoleh menggunakan angket validasi yang diberikan kepada tim ahli yang terdiri dari ahli materi dan ahli media pembelajaran. Masing-masing jawaban diberi skor dengan mengacu kepada skala Likert (Arikunto, 2013).

Tabel 1.

Skor Setiap Pilihan Jawaban Angket

\begin{tabular}{|c|c|}
\hline Skor & Jawaban \\
\hline 5 & Sangat Setuju \\
\hline 4 & Setuju \\
\hline 3 & Netral \\
\hline 2 & Kurang Setuju \\
\hline 1 & Tidak Setuju \\
\hline
\end{tabular}

Setelah responden mengisi angket, nilai dari seluruh responden dirata-ratakan kemudian dinyatakan dalam persentase. Hasil persentase tersebut diinterpretasikan dengan aturan berikut (Arikunto, 2013).

Tabel 2.

Kriteria Penilaian

\begin{tabular}{|c|c|}
\hline Interval (\%) & Kriteria \\
\hline $81-100$ & Sangat Baik \\
\hline $61-80$ & Baik \\
\hline $41-60$ & Cukup \\
\hline $21-40$ & Kurang \\
\hline$<21$ & Kurang Sekali \\
\hline
\end{tabular}

Video dikatakan valid jika masuk pada kriteria Sangat Baik, Baik, atau Cukup (Muna dkk., 2017). Nilai yang diperoleh menjadi dasar untuk melakukan perbaikan terhadap video pembelajaran yang dihasilkan. Setelah direvisi, video kemudian digunakan pada pembelajaran di kelas guna mengetahui praktikalitas dan efektivitas video pembelajaran kalkulus diferensial berbasis pen tablet. Data Praktikalitas diperoleh dengan memberikan angket untuk mengetahui respon mahasiswa terhadap video pembelajaran kalkulus diferensial. Proses analisis praktikalitas dilakukan seperti pada analisis data validitas. Video pembelajaran dikatakan praktis jika masuk pada kategori baik atau sangat baik.

Data efektivitas diperoleh menggunakan instrumen tes berupa soal uraian kalkulus diferensial yang diberikan kepada mahasiswa. Analisis efektivitas dilakukan dengan menghitung rata-rata nilai mahasiswa setelah mengikuti tes yang kemudian dikonversi kedalam rentang 0-100. Interpretasi rata- 
rata nilai yang diperoleh mengacu pada sistem penilaian di Universitas Pasir Pengaraian, yaitu sebagai berikut:

Tabel 3.

Kriteria Penilaian Hasil Belajar

\begin{tabular}{|l|l|l|}
\hline Keterangan & Nilai & Kategori \\
\hline $80 \leq$ rata-rata nilai $\leq 100$ & A & Sangat Baik \\
\hline $65 \leq$ rata-rata nilai $<80$ & B & Baik \\
\hline $55 \leq$ rata-rata nilai $<65$ & C & Cukup \\
\hline $45 \leq$ rata-rata nilai $<65$ & D & Kurang \\
\hline $0 \leq$ rata-rata nilai $<45$ & E & Gagal \\
\hline
\end{tabular}

\section{HASIL}

Pengembangan video pembelajaran kalkulus differensial pada penelitian ini dilakukan melalui tiga fase, yaitu: preliminary research, prototyping stage, assessment phase. Hasil yang diperoleh pada setiap tahapan dijelaskan sebagai berikut.

\section{Preliminary Research}

Pada tahap ini dilakukan analisis kurikulum, analisis materi ajar, analisis video pembelajaran, diskusi dengan teman sejawat tentang permasalahan yang ditemui di lapangan, dan mempelajari karakteristik mahasiswa. Dari kegiatan analisis kurikulum dan materi ajar diperoleh hasil tentang cakupan materi pada mata kuliah kalkulus diferensial. Luaran dari kegiatan ini dihasilkan silabus dan SAP kalkulus diferensial. Dari kegiatan diskusi dengan teman sejawat dan analisis karakteristik mahasiswa diperoleh beberapa hasil diantaranya yaitu: mahasiswa memiliki kemampuan yang relatif rendah pada perkuliahan kalkulus diferensial yang disebabkan oleh kurangnya pemahaman terhadap materi-materi dasar kalkulus diferensial, mahasiswa sering lupa dengan materi sebelumnya, dan mahasiswa sulit memahami penjelasan dari buku teks. Berdasarkan hal tersebut, maka ditetapkan materi yang dibuat video pembelajarannya yaitu materi awal pada kalkulus diferensial yang terdiri dari sistem bilangan real, persamaan dan pertidaksamaan, menggambar grafik persamaan, dan fungsi.

Selanjutnya dilakukan perancangan mengenai bentuk video yang dibuat, cara menyajikannya, pembagian materi pada setiap video, durasi video, soal-soal yang disajikan, serta peralatan yang diperlukan dalam pembuatan video. Video yang dibuat adalah video pembelajaran yang dibuat dengan menggunakan pen tablet. Adapun pengajar pada video ini adalah dosen pengampu mata kuliah kalkulus diferensial yang merupakan peneliti sendiri.

Penyajian materi pada video dimulai dengan penjelasan materi, diikuti contoh soal, dan diakhiri dengan soal latihan untuk dikerjakan mahasiswa. Durasi waktu untuk setiap video maksimal 20 menit. Video sengaja tidak dibuat dengan durasi yang relatif singkat agar tidak membosankan ketika ditonton. Setiap sub materi dibahas dalam satu atau beberapa video. Jika suatu sub materi 
memiliki cakupan materi yang luas, maka pembahasan pada sub materi tersebut dibagi menjadi beberapa video terpisah dengan memperhatikan durasi video agar tidak melebihi 20 menit.

Rancangan banyak video pada masing-masing sub materi adalah sebagai berikut: sub materi sistem bilangan real dibahas dalam 3 video. Sub materi pemfaktoran dibahas dalam 2 video. Sub materi menyelesaikan persamaan dibahas dalam 1 video. Sub materi pertidaksamaan dibahas dalam 2 video. Sub materi menggambar grafik persamaan dibahas dalam 2 video. Sub materi fungsi dibahas dalam 3 video. Sehingga total ada 13 video pembelajaran.

Soal-soal yang disajikan pada video diambil dari soal yang ada dibuku perkuliahan yang digunakan dosen dan mahasiswa. Hal ini dimaksudkan agar penjelasan yang ada dibuku dan divideo dapat saling melengkapi sehingga semakin memudahkan mahasiswa dalam memahaminya.

Peralatan yang diperlukan pada pembuatan video ini yaitu Laptop, Pen Tablet, Microfon. Sedangkan software yang dipakai dalam pembuatan video yaitu Medibang Paint Pro sebagai software untuk menulis, Wondershare Filmora Scrn untuk melakukan Screen Recording, Wondershare Filmora9 untuk editing video, serta Youtube sebagai media untuk menonton video oleh mahasiswa.

\section{Prototyping Stage}

Tahapan ini merupakan tahap pembuatan video pembelajaran dan melakukan evaluasi untuk mengukur validitas video berdasarkan penilaian tim ahli. Tahapan dalam pembuatan video adalah sebagai berikut: pertama, menyiapkan materi yang akan dibahas serta peralatan dan software yang digunakan untuk membuat video. Kedua, Pen tablet dan laptop dihubungkan dengan menggunakan kabel USB. Ketiga, menghidupkan software Wondershare Filmora Scrn untuk merekam setiap aktifitas pada layar komputer. Keempat, Dosen menjelaskan materi sambil menulis penjelasan pada pen tablet. Setiap yang ditulis pada pen tablet akan tampil pada layar laptop dan direkam oleh Wondershare Filmora Scrn. Melalui aktifitas ini akan dihasilkan video pembelajaran yang masih mentah. Kelima, video mentah tersebut di edit melalui software Wondershare Filmora9 untuk menghasilkan video pembelajaran yang siap untuk divalidasi. Proses editing dilakukan untuk membuag beberapa potongan video mentah yang tidak berguna atau memuat kesalahan; memperbaiki audio yang kurang baik; menambahkan beberapa tulisan/ animasi; menambahkan intro; menampilkan soal latihan; dan penutup. Keenam, setelah proses editing, dihasilkan video pembelajaran kalkulus diferensial yang berjumlah 13 video sesuai yang dirancang pada tahap sebelumnya. Video ini kemudian di upload di Youtube sebagai media untuk menonton video yang telah dibuat.

Setelah video pembelajaran selesai dibuat, dilanjutkan pada tahap evaluasi. Tahap ini dimaksudkan untuk menilai validitas video pembelajaran. Validitas video pembelajaran dinilai oleh tiga orang ahli materi dan ahli media pembelajaran. Kepada masing-masing ahli diberikan 13 video pembelajaran dan diminta untuk memvalidasinya menggunakan angket yang telah disediakan. Hasil validasi tim ahli materi disajikan pada Tabel 4. 


\section{Tabel 4.}

Hasil Validasi Tim Ahli Materi

\begin{tabular}{|c|l|c|c|c|c|}
\hline No & Aspek Kelayakan Isi & Validator 1 & Validator 2 & Validator 3 & Persentase (\%) \\
\hline 1 & Kesesuaian Materi & 5 & 4 & 5 & 93,33 \\
\hline 2 & Kedalaman materi & 4 & 3 & 4 & 73,33 \\
\hline 3 & Keakuratan konsep dan prosedur & 5 & 5 & 5 & 100 \\
\hline 4 & Keakuratan contoh & 5 & 4 & 5 & 93,33 \\
\hline 5 & Keakuratan soal & 5 & 4 & 4 & 86,67 \\
\hline 6 & Keakuratan istilah-istilah & 5 & 5 & 5 & 100 \\
\hline 7 & Keakuratan notasi dan simbol & 5 & 5 & 5 & 100 \\
\hline 8 & Kualitas penjelasan & 5 & 4 & 5 & 93,33 \\
\hline 9 & Ketepatan Bahasa & 4 & 4 & 5 & 86,67 \\
\hline 10 & Kesederhanaan bahasa & 4 & 4 & 5 & 86,67 \\
\hline 11 & Sistematika penyajian & 5 & 4 & 4 & 86,67 \\
\hline & \multicolumn{2}{|l|}{ Rata-rata } & & 90,91 \\
\hline
\end{tabular}

Berdasarkan hasil validasi tim ahli materi diperoleh persentase nilai pada setiap indikator penilaian yaitu pada rentang $86,67 \%$ - 100\% kecuali pada indikator kedalaman materi dengan persentase nilai 73,33. Rata-rata secara keseluruhan dari seluruh ahli materi yaitu 90,91\%. Sesuai kriteria yang ditetapkan, maka kelayakan isi video pembelajaran ini dikatakan sangat baik.

Tabel 5.

Hasil Validasi Tim Ahli Media Pembelajaran

\begin{tabular}{|c|l|l|l|l|l|}
\hline No & Aspek Kelayakan Tampilan & Validator 1 & Validator 2 & Validator 3 & Persentase (\%) \\
\hline 1 & Kualitas Gambar & 4 & 5 & 4 & 86,67 \\
\hline 2 & Kualitas suara & 5 & 5 & 5 & 100 \\
\hline 3 & Kualitas pencahayaan & 5 & 4 & 5 & 93,33 \\
\hline 4 & Keterbacaan teks & 4 & 4 & 5 & 86,67 \\
\hline 5 & Tata letak teks & 4 & 4 & 4 & 80 \\
\hline 6 & Kemudahan pemutaran video & 5 & 4 & 5 & 93,33 \\
\hline 7 & Kemenarikan video & 4 & 4 & 5 & 86,67 \\
\hline \multicolumn{5}{|l|}{ Rata-rata } \\
\hline
\end{tabular}

Hasil validasi tim ahli media pembelajaran disajikan pada Tabel 5. Berdasarkan hasil validasi tim ahli media pembelajaran, persentase nilai setiap indikator ada pada rentang $86,67 \%-100 \%$. Secara keseluruhan nilai kelayakan tampilan video pembelajaran dari seluruh ahli adalah 89,52\%. Sesuai kriteria yang ditetapkan nilai ini menunjukkan bahwa kelayakan tampilan video masuk kategori sangat baik

Berdasarkan penilaian validitas video dari segi materi maupun tampilan, diperoleh rata-rata nilai validitas video yaitu 90,22\%. Nilai ini masuk pada kriteria sangat baik. Dengan demikian diperoleh hasil bahwa video pembelajaran valid dengan kriteria sangat baik. 
Selain memberikan penilaian dalam bentuk angka, validator juga memberikan beberapa komentar positif yaitu: video pembelajaran yang dikembangkan direkomendasikan untuk digunakan pada pembelajaran kalkulus diferensial; video dibuat dengan durasi yang pas, penjelasan yang baik dan tidak bertele-tele sehingga tidak membosankan untuk ditonton; pembahasan disajikan secara sistematis, singkat, padat, jelas, dan menggunakan bahasa yang mudah dipahami. Selain komentar positif, validator juga memberikan beberapa saran perbaikan yaitu: bagian pendahuluan pada video pembelajaran sebaiknya menampilkan wajah pengajar dan pada beberapa video sebaiknya selama penyajian materi ditampilkan juga wajah dari pengajar untuk mengakomodasi cara belajar mahasiswa yang memiliki kecenderungan gaya belajar visual.

Beberapa masukan dan saran perbaikan dari tim ahli dilakukan, antara lain seperti yang ditampilkan pada gambar berikut.

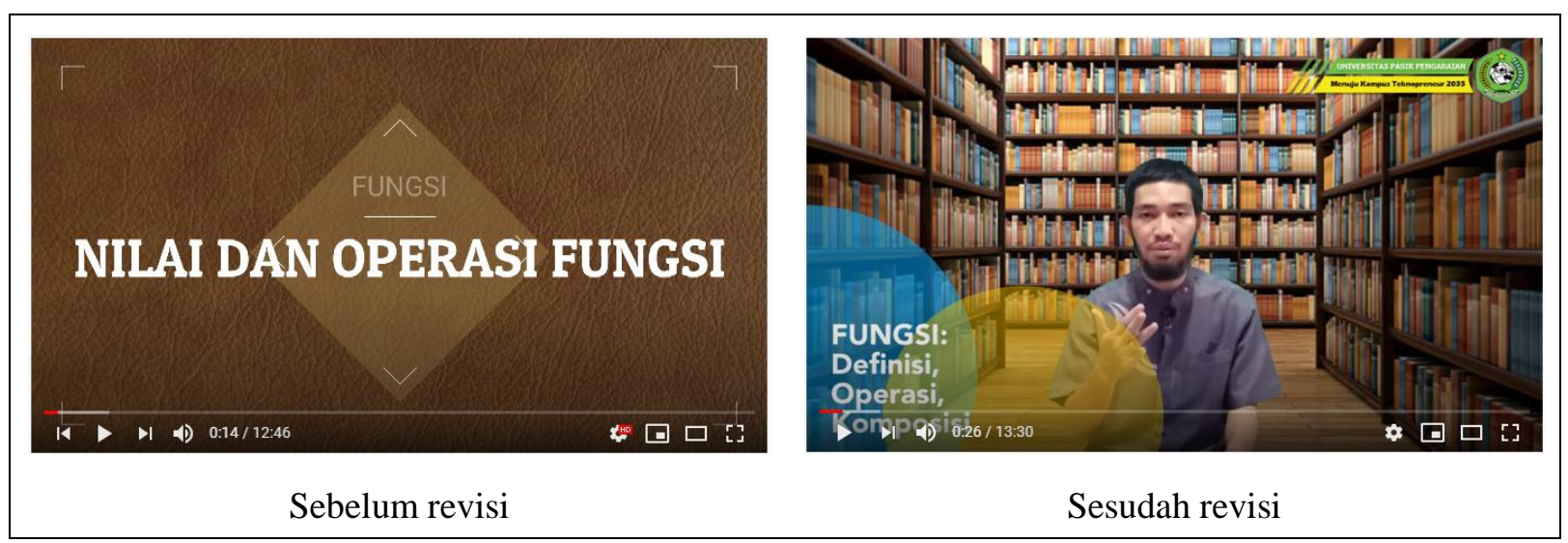

Gambar 2. Revisi Bagian Pendahuluan Video Pembelajaran

Pada video awal, pendahuluan pada setiap video tidak menampilkan wajah pengajar. Hanya menampilkan judul materi yang dibahas pada video tersebut sebagaimana pada gambar bagian kiri (sebelum revisi). Atas masukan dari tim ahli, sebaiknya dibagian pendahuluan tidak hanya menampilkan judul materi saja, tetapi perlu menampilkan wajah pengajar juga. Masukan tersebut dilaksanakan dengan menampilkan wajah pengajar pada bagian pendahuluan sebagaimana terlihat pada gambar bagian kanan (sesudah revisi).

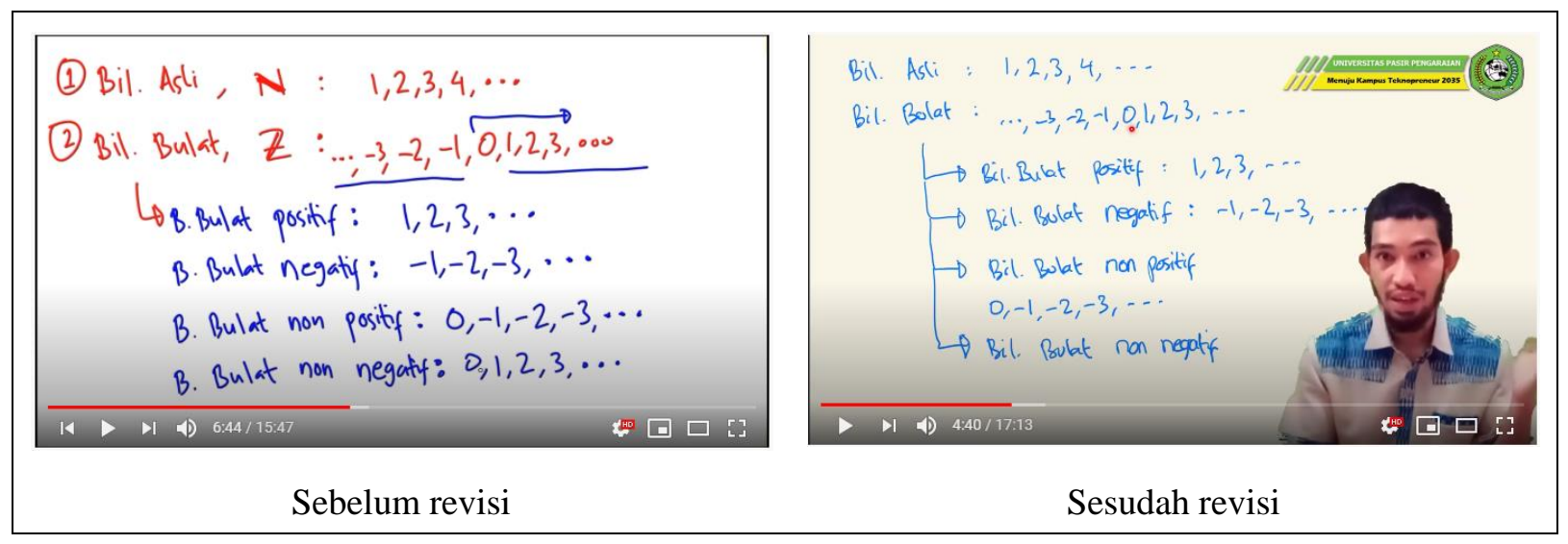

Gambar 3. Revisi Tampilan pada Video Pembelajaran 
Pada video awal, seluruh video hanya menampilkan tulisan dan suara penjelasan dari pengajar. Tidak menampilkan wajah pengajar seperti yang terlihat pada gambar sebelah kiri (sebelum revisi). Salah satu saran dari tim ahli yaitu agar dalam proses pengajaran, pada beberapa video menampilkan juga wajah pengajar untuk memfasilitasi mahasiswa yang bergaya belajar visual, yang perlu melihat pengajarnya. Oleh karena itu pada beberapa video pembelajaran yang dibuat, ditampilkan juga wajah pengajar dibagian pojok kanan bawah video sebagaimana yang terlihat pada gambar sebelah kanan (sesudah revisi).

\section{Assessment Phase}

Tahap ini merupakan tahap penerapan video pembelajaran yang telah dikembangkan. Video yang digunakan adalah video hasil perbaikan pada tahap sebelumnya. Video yang digunakan pada tahap implementasi ada sebanyak 13 video yang dapat dilihat pada link berikut ini https://www.youtube.com/playlist?list=PL9tpTiL RG5FniDov5cUhWJ0jvJnU JLw.

Video pembelajaran digunakan pada perkuliahan kalkulus diferensial pada mahasiswa program studi Pendidikan Matematika Universitas Pasir Pengaraian T.A. 2020/2021. Video pembelajaran digunakan selama setengah semester (tujuh pertemuan) sebelum pelaksaan UTS (Ujian Tengah Semester). Adapun teknis perkuliahan yang dilakukan adalah sebagai berikut. Pertama, kondisi Indonesia pada saat penelitian ini dilaksanakan sedang mengalami pandemi Covid-19 sehingga seluruh perkuliahan diwajibkan dilakukan secara daring. Oleh karena itu, perkuliahan kalkulus diferensial dilaksanakan melalui Smart Learning yang ada pada website universitas. Kedua, video pembelajaran diupload ke Youtube dan tautannya dimasukkan pada Smart Learning. Ketiga, mahasiswa menonton video pembelajaran melalui Smart Learning. Video pembelajaran ini merupakan sumber belajar mahasiswa sebagai pengganti penjelasan dosen di kelas pada perkuliahan normal. Keempat, mahasiswa melakukan diskusi dengan sesama mahasiswa dan juga dosen melalui kolom diskusi yang telah tersedia di Smart Learning. Mahasiswa dapat bertanya hal-hal yang kurang dipahami yang ada pada video pembelajaran.

Setelah melalui tujuh pertemuan, mahasiswa mengikuti UTS. Pada saat UTS, mahasiswa diberikan angket dan ujian tertulis. Angket digunakan untuk mengukur praktikalitas video pembelajaran. Sedangkan soal ujian tertulis digunakan untuk mengukur efektifitas video pembelajaran. Hasil penilaian praktikalitas video pembelajaran disajikan pada Tabel 6.

\section{Tabel 6.}

Hasil Penilaian Praktikalitas Video Pembelajaran

\begin{tabular}{|c|l|c|c|}
\hline No & Aspek Penilaian & Rata-rata Nilai (\%) & Kategori \\
\hline 1 & Kemudahan pemutaran video & 80,00 & Baik \\
\hline 2 & Kenyamanan menonton video melalui Laptop & 77,89 & Baik \\
\hline 3 & Kenyamanan menonton video melalui Smart Phone & 77,50 & Baik \\
\hline 4 & Kejelasan tulisan/teks pada video & 76,00 & Baik \\
\hline 5 & Kejelasan suara pada video & 80,00 & Baik \\
\hline
\end{tabular}




\begin{tabular}{|c|l|c|c|}
\hline 6 & Kemudahan memahami bahasa yang digunakan & 81,60 & Sangat Baik \\
\hline 7 & Kemudahan memahami materi yang disampaikan & 76,00 & Baik \\
\hline 8 & Sistematika penjelasan materi & 78,40 & Baik \\
\hline 9 & Peran video dalam membantu proses belajar & 78,40 & Baik \\
\hline 10 & Peran video sebagai sumber belajar & 79,20 & Baik \\
\hline 11 & Peran video dalam memahami materi perkuliahan & 79,20 & Baik \\
\hline 12 & Peran video dalam mengulangi pelajaran & 77,60 & Baik \\
\hline 13 & Peran video untuk kemudahan dalam belajar & 78,40 & Baik \\
\hline & Rata-rata & $\mathbf{7 8 , 4 8}$ & Baik \\
\hline
\end{tabular}

Berdasarkan Tabel 6, seluruh aspek penilaian berada pada kategori "baik", kecuali pada indikator "kemudahan memahami bahasa yang digunakan" berada pada kategori "sangat baik. Secara umum dapat dikatakan bahwa video pembelajaran memiliki tingkat kepraktisan yang baik. Meskipun demikian, aspek yang memperoleh penilaian terendah salah satunya adalah "kemudahan dalam memahami materi yang disampaikan" dengan rata-rata nilai $76,00 \%$. Hal ini berarti video pembelajaran belum mampu membuat seluruh mahasiswa memahami materi dengan sangat baik. Artinya masih ada mahasiswa yang merasa sulit untuk memahami materi yang ada pada video. Hal ini tidak terlepas dari kemampuan akademik mahasiswa pada universitas lokasi penelitian yang memang kebanyakan masih rendah. Hal ini sesuai dengan hasil penelitian sebelumnya yang dilakukan oleh (Ario, 2019) yang menunjukkan bahwa kemampuan awal mahasiswa pada universitas lokasi penelitian ini masih rendah dengan rata-rata penguasan materi yaitu 19,55\%. Hal ini dapat dimaklumi karena universitas lokasi penelitian ini merupakan universitas swasta kecil. Mahasiswa pada universitas ini merupakan mahasiswa yang umumnya tidak lulus pada universitas terkemuka lainnya. Namun demikian hasil ini memberikan suatu petunjuk bahwa video pembelajaran berikutnya harus dibuat dengan memperhatikan kemampuan akademik mahasiswa. Setiap penjelasan materi harus diperkirakan dapat dipahami oleh mahasiswa dari berbagai tingkat kemampuan akademik yang beragam, khususnya oleh mahasiswa dengan kemampuan akademik rendah.

Penilaian tertinggi ada pada aspek "kemudahan dalam memahami bahasa yang digunakan" dengan rata-rata nilai $81,60 \%$ dengan kategori sangat baik. Hasil ini sesuai dengan apa yang peneliti lakukan dalam pembuatan video. Bahasa yang digunakan memang bahasa yang sederhana dan akrab bagi mahasiswa. Peneliti menghindari penggunaan kata-kata atau istilah yang kemungkinannya belum familiar bagi mahasiswa. Hal ini mengingat bahwa mahasiswa pada perkuliahan kalkulus diferensial merupakan mahasiswa semester 1 yang baru saja tamat dari tingkat sekolah yang kemungkinan perbendaharaan kata atau istilahnya belum terlalu banyak. Namun demikian hasil penelitian ini menunjukkan bahwa bahasa sederhana dan mudah dipahami belum tentu menjamin secara otomatis mahasiswa akan mudah dalam memahami materi. 
Secara keseluruhan, rata-rata nilai praktikalitas video pembelajaran adalah $78,48 \%$. Nilai ini masuk pada kriteria baik. Dengan demikian dapat dikatakan bahwa video pembelajaran praktis untuk digunakan.

Selain memberikan angket, pada akhir tahap implementasi dilaksanakan tes untuk mengukur tingkat penguasaan materi mahasiswa. Tes diberikan dalam bentuk soal uraian. Hasil tes digunakan untuk menilai efektifitas pembelajaran. Hasil tes mahasiswa ditunjukkan pada Tabel 7 dan Tabel 8 berikut.

\section{Tabel 7.}

Deskripsi Data Hasil Tes

\begin{tabular}{|c|c|c|c|c|}
\hline Indikator & $\bar{x}$ & $x_{\min }$ & $x_{\max }$ & SD \\
\hline Nilai & 71,32 & 49 & 98 & 9,47 \\
\hline
\end{tabular}

Tabel 7 menunjukkan bahwa rata-rata hasil belajar mahasiswa yaitu 71,32. Nilai ini masuk pada kategori Baik. Masih ada mahasiswa yang memiliki nilai rendah yaitu 49. Artinya mahasiswa tersebut hanya mampu menguasai setengah dari materi yang diajarkan. Namun demikian terdapat juga mahasiswa yang hampir menguasai materi dengan sangat baik. hal ini ditandai dengan raihan skor mencapi 98. Adaapun persebaran nilai dari 40 mahasiswa yang menjadi subjek penelitian ini disajikan pada Tabel 8.

Tabel 8.

Persebaran Nilai Mahasiswa

\begin{tabular}{|c|c|c|c|}
\hline Kriteria & Nilai & Banyak Mahasiswa & Persentase $(\%)$ \\
\hline $80 \leq$ Nilai $\leq 100$ & A & 9 & 22,50 \\
\hline $65 \leq$ Nilai $<80$ & B & 23 & 57,50 \\
\hline $55 \leq$ Nilai $<65$ & C & 8 & 20,00 \\
\hline $45 \leq$ Nilai $<55$ & D & 0 & 0,00 \\
\hline $0 \leq$ Nilai $<45$ & E & 0 & 0,00 \\
\hline \multicolumn{2}{|c|}{ TOTAL } & 40 & 100 \\
\hline
\end{tabular}

Berdasarkan data yang disajikan pada Tabel 8, dapat diketahui bahwa sebagian besar mahasiswa $(57,50 \%)$ memperoleh nilai B. Rata-rata kelas yang diperoleh yaitu 71,32 yang masuk pada kriteria Baik. Dengan demikian dapat dikatakan bahwa video pembelajaran efektif untuk penguasaan materi mahasiswa. Namun demikian, hasil yang diperoleh ini masih belum ideal karena masih terdapat $20 \%$ mahasiswa yang memperoleh nilai rendah (C) dan masih sedikit $(22,50 \%)$ mahasiswa yang memperoleh nilai A.

\section{KESIMPULAN}

Secara keseluruhan hasil penelitian ini menunjukkan bahwa video pembelajaran kalkulus diferensial berbasis pen tablet yang dikembangkan valid, praktis, dan efektif. Nilai validitas video masuk pada kategori sangat baik sedangkan praktikalitas dan efektifitas masuk pada kategori baik. Adapun saran untuk penelitian berikutnya yang akan mengembangkan video pembelajaran, sebaiknya 
terlebih dahulu dilakukan penelitian awal tentang tingkat kemampuan akademik mahasiswa agar video pembelajaran yang dibuat dapat disesuaikan dengan tingkat kemampuan mahasiswa dalam memahami materi.

\section{DAFTAR PUSTAKA}

Anggraeni, A. A., Nugraheni, M., \& Handayani, T. H. W. (2019). Pengembangan Video Pembelajaran Mata Kuliah Teknologi Pengawetan Makanan Materi Kacang Disko. Home Economics Journal, 1(1), 12-20. https://doi.org/10.21831/hej.v1i1.23281

Arikunto. (2013). Dasar-dasar Evaluasi Pendidikan. Jakarta: Bumi Aksara.

Ario, M. (2019). Profil Kemampuan Awal Matematis Mahasiswa Pendidikan Matematika. Jurnal Absis: Jurnal Pendidikan Matematika dan Matematika, 1(2), 72-77. https://doi.org/10.30606/absis.v1i2.90

Ario, M. (2019). Pengembangan video pembelajaran materi integral pada pembelajaran flipped classroom. AKSIOMA: Jurnal Program Studi Pendidikan Matematika, 8(1), 20-31. https://doi.org/10.24127/ajpm.v8i1.1709

Chandra, F. H., \& Nugroho, Y. W. (2016). Peran teknologi dalam flipped calssroom. Dinamika Teknologi, 8(1), 15-20.

Muna, H., Nizaruddin, N., \& Murtianto, Y. H. (2017). Pengembangan video pembelajaran matematika berbantuan macromedia flash 8 dengan pendekatan kontekstual pada materi program linier kelas XI. AKSIOMA, 8(2), 9-18. https://doi.org/10.26877/aks.v8i2.1686

Plomp, T., \& Nieveen, N. M. (2010). An introduction to educational design research: proceedings of the seminar conducted at the East China Normal University, Shanghai (PR China), November 23-26, 2007. http://www.slo.nl/downloads/2009/Introduction_20to_20education_20design_ 20research.pdf/download

Pritandhari, M., \& Ratnawuri, T. (2015). Evaluasi penggunaan video tutorial sebagai media pembelajaran semester IV program studi Pendidikan Ekonomi Universitas Muhammadiyah Metro. PROMOSI (Jurnal Pendidikan Ekonomi), 3(2), 11-20. https://doi.org/10.24127/ja.v3i2.329

Purwanti, B. (2015). Pengembangan Media Video Pembelajaran Matematika dengan Model Assure. Jurnal Kebijakan dan Pengembangan Pendidikan, 3, 42-47. https://doi.org/10.22219/jkpp.v3i1.2194

Rebowo, W. A. (2014). Pengembangan media video pembelajaran berbasis masalah materi pecahan pada siswa kelas IV sekolah dasar. Pelangi Pendidikan, 21(2), 94-106. https://doi.org/10.24114/pelangi.v21i2.2752

Rhine, S. (2015). The Role of Technology in Increasing Preservice Teachers' Anticipation of Students' Thinking in Algebra. Contemporary Issues in Technology and Teacher Education, 15(2), 85-105.

Saloko, A., Jampel, I. N., \& Suwatra, I. W. (2013). Pengembangan media video pembelajaran mata 
pelajaran matematika pada siswa kelas V SD Negeri 2 Seririt tahun pelajaran 2012/2013 semester ganjil. Jurnal Edutech, 1(2), 51-61. http://dx.doi.org/10.23887/jeu.v1i2.1501

Sugiyono. (2015). Metode Penelitian \& Pengembangan (Research and Development). Bandung: Alfabeta. 